\title{
ZAKAT DALAM SEJARAH UMAT PRA-KENABIAN MUHAMMAD
}

\author{
Mohammad Subhan Zamzami \\ (Program Pascasarjana UIN Sunan Ampel Surabaya, jln. A. Yani 117 Surabaya, \\ email:mbahsidi@yahoo.com )
}

\begin{abstract}
Abstrak
Al-Qur'an dan Hadits sering menyinggung persoalan persamaan dan perbedaan ritual antara Islam dengan Kristen dan Yahudi yang sama-sama sebagai agama sah Ibrahim. Salah satu persamaan ritual tersebut adalah kewajiban mengeluarkan zakat. Dalam tulisan ini, penulis mengkaji persoalan zakat dalam syarî́ah terdahulu dengan menggunakan metode tafsir tematik. Dalam kaitan ini, alQur`an menampilkan kata zakah dalam tiga gaya bahasa (uslûb). Pertama, menggunakan uslûb insyâ'iy, yaitu berupa perintah, dengan menggunakan kata $\hat{a} t \hat{u}$, anfiqû, dan khuzh. Kedua, menggunakan uslûb targhîb (motivatif). Ketiga, menggunakan uslîb tarhîb (intimidasi). Keempat, menggunakan uslûb madh (pujian). Karena fokus penelitian ini hanya menyangkut ayat-ayat pokok tentang zakat terdahulu, maka hanya kata-kata dalam ayat pokok itu yang dianalisis berdasarkan tiga gaya bahasa (uslûb) ini. Dalam surat Maryam ayat 31, al-Qur`an menggunakan kata awshâ, dalam surat Maryam ayat 55, al-Qur`an menggunakan kata ya'muru, dalam surat al-Anbiyâ' ayat 73, al-Qur`an menggunakan gabungan kata awh hâ dan $\hat{\imath} t \hat{a}^{\prime}$, dalam surat al-Baqarah ayat 83, al-Qur`an menggunakan kata $\hat{a} t \hat{u}$, dalam surat al-Mâ'idah ayat 12 , al-Qur`an menggunakan gabungan kata umirû dan âtaytum. Dalam keenam ayat di atas, al-Qur`an sama-sama menggunakan gaya bahasa perintah (uslûb insyấ) dibuktikan dengan konsekuensi serius bagi pengingkar zakat.
\end{abstract}

\begin{abstract}
The Qur'an and Hadits often talk about the ritual similarities and differences of problem between Islam, Christianity and Jewish which are the legal religion of Ibrahim. One of ritual similarities is the compulsory of tithe (zakat). In this writing, the writer discusses tithe problem in the previous syaríah by
\end{abstract}


using thematic exegesis method. In this context, the Qur'an states the word zakah in three language styles (uslûb). First, using uslûb insyấ'i, that is command, by using the words $\hat{a} t \hat{u}$, anfiq $\hat{u}$, dan khuzh. Second, using uslûb targhîb (motivatif). Third, using uslûb tarhîb (intimidation). Fourth, using uslûb madh (praise). Since the focus of this research only describes the main verses of previous tithe, so only the words in that main verses analyzed based on these three language styles (uslûb). In the surrah of Maryam, the Qur'an uses the word awshâ (the verse 31 ), the Qur'an using the word ya'muru (the verse 55), in the surrah of al-Anbiyâ', the Qur'an using the combination of the word of $a w h \hat{a}$ and $\hat{\imath} t \hat{a}$ (the verse 73), in Surrah of al-Baqarah, the Qur'an using the word ât $\hat{u}$ (the verse 83), in Surrah of alMâ'idah, the Qur'an using the combination of the words of umiru and attaytum (the verse of 12). From those six verses, alQur'an use command style (uslûb insyâ'î). This can be proven by serious consequence for tithe breaker.

\section{Kata-kata Kunci}

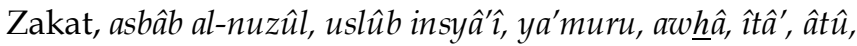
umirû, âtaytum

\section{Pendahuluan}

Wacana titik temu-titik tengkar agama-agama samawi sudah lama bergulir. Sejatinya Islamlah yang pertama mengangkat wacana ini ke permukaan. Sebagai bukti, sebelum para sarjana Barat gencar menggulirkan wacana ini, para sarjana klasik Islam telah menuangkannya dalam buku-buku perbandingan sekte dan agama (kutub al-firâq wa al-milâl wa al-nihâl). Inspirasi sekaligus penopang kajian mereka adalah al-Quran dan Hadits. Dua sumber doktrin utama Islam itu sering menyinggung persoalan persamaan dan perbedaan ritual antara Islam dengan Kristen dan Yahudi yang samasama mengklaim sebagai agama sah Ibrahim (abrahamic religions).

Salah satu ritual tersebut adalah kewajiban mengeluarkan zakat. Dalam Islam, zakat merupakan salah satu rukun iman. Konsekuensinya, bila ada orang Islam yang menolak mengeluarkan zakat, maka status keislamannya tidak sah alias murtad. Oleh karena itu, Abû Bakr al-Shiddîq (w. 13 H/634 M) dengan tegas mengecam seraya memerangi mereka yang menolak mengeluarkan zakat di masa awal kekhalifahannya yang dikenal dengan harb al-riddah. 
Dalam literatur Islam, kajian seputar persoalan zakat dalam Islam sangat banyak, baik berupa buku khusus, artikel maupun pembahasan sisipan dalam literatur figh. Oleh karena itu, agar tidak terkesan monoton, penulis perlu mengkaji persoalan zakat dalam aspek yang berbeda, yaitu persoalan zakat dalam syarî'ah-syarî'ah terdahulu dengan menggunakan metode tafsir tematik.

Dengan metode ini, penulis mengkaji seluruh ayat al-Qur`an yang berkenaan dengan zakat dalam syarî'ah terdahulu sebagai ayat pokok pembahasan seraya tidak mengabaikan ayat al-Qur an yang berkenaan dengan zakat dalam syarî́ah Islam dan ayat al-Qur'an lain yang berkaitan dengan ayat pokok sebagai ayat penunjang, asbâb alnuzûl ayat pokok, Hadits Nabi Muhammad saw., dan secuil tentang sejarah umat terdahulu.

Dalam tulisan ini, ayat-ayat pokok tersebut disusun berdasarkan kronologi turunnya sesuai dengan asbâb al-nuzĥul-nya dengan, bila ada, mencantumkan teks asbâb al-nuzĥul seraya memerhatikan korelasi antara ayat pokok dengan ayat sebelum dan sesudahnya serta ayat-ayat zakat penunjang lainnya. Ada pun Hadits dan sejarah umat terdahulu, maka keduanya berfungsi sebagai informasi penyempurna. Urutan ini sesuai dengan metode tafsir tematik.

\section{Definisi dan Istilah Zakat dalam al-Qur’an}

Dalam Lisân al-'Arab, kata al-Zakâh berasal dari kata zakâ. Ibn Manzhûr (630-711 H/1232-1311 H) menyebutkan dua definisi alZakâh. Pertama, al-Zakâh bermakna al-shalâh (kesalehan) dengan empat bentuk kata kerja yaitu zakâ, zakiya, zakkâ, dan tazakkâ. Kedua, al-Zakâh bermakna zakat harta atau penyucian harta dengan satu bentuk kata kerja yaitu zakkâ. Al-Zakâh adalah harta yang dikeluarkan untuk menyucikan harta itu dengannya. ${ }^{1}$

Pendapat senada dilontarkan al-Thabârî. Menurutnya, asal kata al-zakâh adalah namấ al-mâl wa tathmîruhu wa ziyâdatuhu. Zakat adalah harta yang berasal dari harta. Ia dinamakan zakat karena untuk mengagungkan Allah dengan cara mengeluarkan sisa harta kepada Tuhan yang menciptakan harta itu dari yang dia miliki. Boleh jadi juga ia dinamakan zakat karena ia merupakan penyucian bagi

1Ibn Manzhûr, Lisân al-'Arab, juz 21 (Kairo: Dâr al-Ma'ârif, t.t.), hlm. 1849. 
sisa harta yang dimiliki seseorang. ${ }^{2}$ Oleh karena itu, definisi kedua Ibn Manzhûr dan al-Thabârî ini merupakan definisi acuan tulisan ini.

Di dalam al-Qur'an terdapat 32 kata zakat, dan 82 kali diulang dengan menggunakan istilah yang merupakan sinonim dari kata zakat, yaitu kata shadaqah dan infâq. Nuruddin menambahkan bahwa teks al-Qur'an tentang zakat diturunkan dalam dua periode, yaitu periode Makkah sebanyak delapan ayat dan periode Madinah sebanyak 24 ayat. $^{3}$ Berdasarkan al-Mu'jam al-Mufahras li Alfâzh alQur'ân al-Karîm karya Muhammad Fu'âd 'Abd al-Bâqî dan Konkordansi Qur'an karya Ali Audah, ada 32 kata zakat dalam alQur’an. Sebanyak 28 ayat di antaranya selalu diiringi dengan kata salat, sedangkan lima ayat lainnya hanya mencantumkan kata zakat saja.

Karena alasan metodologis dan keterbatasan ruang, maka penulis tidak menulis 32 kata zakat dalam al-Qur`an tersebut satu persatu di sini, tetapi cukup dengan mencantumkan nama surat dan nomor ayatnya sebagai berikut:

1. Surat al-Baqarah ayat $43,83,110,177$, dan 277;

2. Surat al-Nisâ' ayat 77 dan 162;

3. Surat al-Mâ'idah ayat 12 dan 55;

4. Surat al-A'râf ayat 156;

5. Surat al-Tawbah ayat 5, 11, 18, dan 71;

6. Surat al-Kahfi ayat 81 ;

7. Surat Maryam ayat 13, 31, dan 55;

8. Surat al-Anbiyâ' ayat 73;

9. Surat al-Hajj ayat 41 dan 76;

10. Surat al-Mu'minûn ayat 4 ;

11. Surat al-Nûr ayat 37 dan 56;

12. Surat al-Naml ayat 3;

13. Surat al-Rûm ayat 39;

14. Surat Luqmân ayat 4;

\footnotetext{
2 Abû Ja'far Muhammad ibn Jarîr al-Thabarî, Jâmi' al-Bayân 'an Ta'wîl Âyi al-Qur'ân, juz 1 (Kairo: Dâr Hijr, 2001), hlm. 611-612.

3 Nuruddin Mhd. Ali, Zakat sebagai Instrumen dalam Kebijakan Fiskal (Jakarta: RajaGrafindo Persada, 2006), hlm. 24-25.
} 
15. Surat al-Ahzâb ayat 33;

16. Surat Fushshilat ayat 7;

17. Surat al-Mujâdalah ayat 13;

18. Surat al-Muzammil ayat 20;

19. Surat al-Bayyinah ayat 5.4

Ini berarti hasil penelitian penulis mengukuhkan hasil penelitian Abdurrahman Qadir sebelumnya yang menyebutkan 32 kata zakah. Di antara 32 ayat tersebut, sebanyak lima ayat hanya mencantumkan kata zakah saja tanpa diiringi dengan kata shalâh termaktub dalam surat al-Kahfi ayat 81, surat Maryam ayat 13, surat al-Mu' minûn ayat 4, surat al-Rûm ayat 39, dan surat Fushshilat ayat 7 .

Di antara 32 ayat zakat di atas, hanya 6 ayat yang berkaitan dengan persoalan zakat dalam syarî'ah terdahulu. Urutan 6 ayat tadi berdasarkan urutan turunnya sebagai berikut:

1. Surat Maryam ayat 31

2. Surat Maryam ayat 55

3. Surat al-Anbiyâ' ayat 73

4. Surat al-Baqarah ayat 83

5. Surat al-Mầidah ayat 12

6. Surat al-Bayyinah ayat 5

Di antara ayat-ayat tersebut, penulis tidak menemukan sabab al-nuzûl khusus surat Maryam ayat 31 baik dalam literatur utama asbâb al-nuzûl semisal asbâb al-nuzĥul karya Abû al-Hasan 'Alî ibn Ahmad al-Wâhidî al-Naysâbûrî (w. 468 H), al-'Ujâb fî̀ Bayân al-Asbâb karya Ibn hajar al-'Asqalânî (773-852 H), Lubâb al-Nuqûl fí Asbâb alNuzûl karya Jalâl al-Dîn Abû 'Abd al-Rahman al-Suyûthî (w. 911 H), al-Shahîh al-Musnad min Asbâb al-Nuzûl karya Abû 'Abd al-Rahman Muqbil ibn Hâdî al-Wâdi'î, dan al-Shahîh min Asbâb al-Nuzûul karya

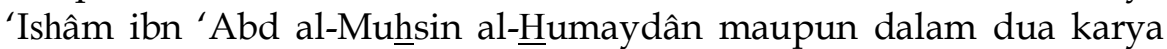
tafsir terbaik semisal Jâmi' al-Bayân 'an Ta'wîl Âyi al-Qur'ân karya Abû

\footnotetext{
4 Muhammad Fu'âd 'Abd al-Bâqî, al-Mu'jam al-Mufahras li Alfâzh al-Qur'ân al-Karîm, juz 1 (Kairo: Dâr al-Hadîts, 1939), hlm. 331-332, dan Ali Audah, Konkordansi Qur'an: Panduan Kata dalam Mencari ayat Qur'an (Bogor: Pustaka Litera AntarNusa, 1997), hlm. 803-804,
} 
Ja'far Muhammad ibn Jarîr al-Thabarî (224-310 H) dan Tafsîr al-Qur'ân al-'Azhîm karya Abû al-Fidâ' Ismâ'îl ibn 'Umar ibn Kathîr al-Qurashî al-Dimasyqî (700-774 H).

Ketiadaan rekaman sabab al-nuzĥl bukan berarti posisi ayat ini di antara ayat-ayat lainnya sama sekali tidak bisa dilacak, karena fakta bahwa surat Maryam termasuk surat Makkiyah menunjukkan bahwa surat ini turun sebelum Nabi Muhammad saw. hijrah ke Madinah. Bahkan berdasarkan riwayat Muhammad ibn Ishâq yang dikutip oleh Ibn Kathîr dikatakan bahwa Ja'far ibn Abû Thâlib membaca pembukaan surat ini kepada Negus di Ethiopia ketika sebagian umat Islam hijrah ke sana. ${ }^{5}$ Ini menunjukan surat ini turun pada masa awal kemunculan Islam di Makkah. Hal yang sama terjadi pada surat Maryam ayat 31, Surat al-Anbiyâ' ayat 73, Surat al-Baqarah ayat 83, dan surat al-Mâ'idah ayat 12 .

Dari semua ayat di atas, Nuruddin Mhd. Ali menyebutkan bahwa al-Qur'an menampilkan kata zakah dalam tiga gaya bahasa (uslûb). Pertama, menggunakan uslûb insyâ'iy, yaitu berupa perintah, dengan menggunakan kata âtû, anfiqû, dan khuzh. Kedua, menggunakan uslûb targhîb (motivatif). Ketiga, menggunakan uslûb tarhîb (intimidatif/peringatan). Keempat, menggunakan uslûb madh (pujian/sanjungan). ${ }^{6}$ Karena fokus penelitian ini hanya menyangkut ayat pokok tentang zakat terdahulu, maka hanya kata-kata dalam ayat pokok itu yang dianalisis berdasarkan tiga gaya bahasa (uslûb) ini.

Pertama, dalam surat Maryam ayat 31, al-Qur'an menggunakan kata awshâ. Kata ini berasal dari kata washâ.7 Awshâ yang memiliki bentuk mashdar $\hat{\imath} s \hat{a}^{\prime}$ dan washshâ yang memiliki bentuk mashdar tawshiyah memiliki arti yang sama. Kalimat awshâ al-rajula wa washshâhu bermakna 'ahida ilayhi. ${ }^{8}$ Oleh karena itu, maka redaksi ayat ini menggunakan gaya bahasa perintah (uslûb insyâ'

Kedua, dalam surat Maryam ayat 55, al-Qur’an menggunakan kata ya'muru. Kata ini merupakan bentuk fi'il mudlâri' dari kata amara dan amr serta imâr adalah bentuk mashdar-nya, yang menurut Ibn Manzhûr

5Abū al-Fidâ' Ismâ'îl ibn 'Umar ibn Katsîr al-Qurasyî al-Dimasyqî, Tafsîr al-Qur'ân al'Azhîm, juz 5 (Riyad: Dâr al-Thaybah, 1999), hlm. 211.

${ }^{6} \mathrm{Ali}$, Zakat sebagai Instrumen, hlm. 26.

7Ibn Manzhûr, Lisân al-'Arab, hlm. 345.

8Ibid., vol. 25, hlm. 4854. 
adalah antonim kata al-nahyu. ${ }^{9}$ Oleh karena itu, maka redaksi ayat ini menggunakan gaya bahasa perintah (uslûb insyâ'î).

Dalam surat al-Anbiyâ' ayat 73, al-Qur'an menggunakan gabungan kata awhâ dan $\hat{\imath} t \hat{a}^{\prime}$. Kata $a w \underline{h} \hat{a}$ berasal dari kata wahâa. AlWahyu bermakna al-Ishârah, al-Kitâbah, al-Risâlah, al-Ilhâm, al-Kalâm alKhafiy, dan kullu mâ alqaytahu ilâ ghayrika. Kadang wahâ semakna dengan awhâ. Awhâa juga bermakna ba'atha, alhama, dan amara. ${ }^{10}$ Sementara itu, kata $\hat{\imath} t \hat{a}^{\prime}$ berasal dari kata atâ. İt $\hat{a}^{\prime}$ merupakan bentuk mashdar dari kata $\hat{a} t a ̂ . \bar{I} t \hat{a}^{\prime}$ adalah sinonim kata $i^{\prime} t \hat{a}^{\prime} .11$ Oleh karena itu, maka redaksi ayat ini menggunakan gaya bahasa perintah (uslûb insyấ'

Dalam surat al-Baqarah ayat 83, al-Qur`an menggunakan kata âtû. Kata ini adalah bentuk fi'il amr (kata kerja perintah) yang berasal dari akar kata atâ di atas. Oleh karena itu, maka redaksi ayat ini menggunakan gaya bahasa perintah (uslûb insyâa'

Dalam surat al-Mâ'idah ayat 12, al-Qur`an menggunakan gabungan kata umirû dan âtaytum. Kata umirû merupakan bentuk

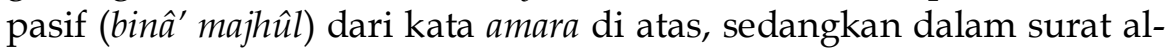
Bayyinah ayat 5, al-Qur'an menggunakan kata yu't $\hat{u}$ yang berasal dari kata atâ di atas. Baik kata umirû dan yu'tû meskipun bukan bentuk kata perintah langsung, tetapi mengandung makna perintah. Oleh karena itu, maka redaksi dua ayat ini menggunakan gaya bahasa perintah (uslûb insyấ' î). Jadi, enam ayat pokok penelitian ini samasama menggunakan gaya bahasa perintah. Ini bisa dibuktikan dengan konsekuensi serius bagi pengingkar zakat dalam uraian selanjutnya.

\section{Zakat dalam Sejarah Umat Prakenabian Muhammad}

Salah satu misi al-Qur`an adalah sebagai informasi tentang sejarah umat prakenabian Muhammad saw. Ia mengungkapkan sekilas tentang ritual, ekonomi, dan politik mereka, baik agama samawi - ajaran para nabi dan rasul pra-Muhammad saw. - maupun agama non-samawi. Penulis tidak akan mengungkit persoalan ekonomi dan politik mereka, tetapi hanya fokus pada ritual yang dalam ini adalah persoalan zakat dalam agama samawi karena dua

9Ibid., vol 1, hlm. 125.

10Ibid., vol. 53, hlm. 4788.

11lbid., vol. 1, hlm. 23. 
alasan utama. Pertama, meskipun zakat pada sejarah perkembangannya erat kaitannya dengan perekonomian, tetapi dalam konteks syarî'ah terdahulu ia lebih identik dengan ritual keagamaan. Kedua, kata syarî'ah dalam penelitian ini lebih identik dengan syarî'ah agama samawi.

Dari segi sejarah, menurut Nuruddin Mhd. Ali, "kewajiban zakat telah disyariatkan kepada para nabi dan rasul sebagaimana telah dilaksanakan oleh Nabi Ibrahim as. dan Nabi Ismâ'il as. Bahkan terhadap Bani Israil, umat Nabi Mûsâ as. syarî'ah zakat telah diterapkan. Demikian pula terhadap umat Nabi Isa As. ketika Isa As. masih dalam buaian. Ahli kitab juga diperintahkan untuk menunaikan zakat sebagai salah satu instrumen agama yang hanîf (lurus)."12

Dia melandaskan pendapatnya pada informasi al-Qur`an. Dia mengacu pada surat al-Anbiyâ' ayat 73 untuk persoalan zakat dalam syarî́ah Nabi Ibrahim As., pada surat Maryam ayat 55 untuk persoalan zakat dalam syarî'ah Nabi Ismâ' il As., pada surat al-Baqarah ayat 83 untuk persoalan zakat dalam syarî'ah Nabi Mûsâ As. atas Bani Israil, pada surat Maryam ayat 31 untuk persoalan zakat dalam syarî'ah Nabi Isa As., dan pada surat al-Bayyinah ayat 5 untuk persoalan zakat atas Ahli Kitab. Hanya saja, dia tidak menyebutkan surat al-Mâ'idah ayat 12. Padahal salah satu kandungan ayat terakhir ini adalah perintah zakat terhadap Bani Israil.

Bani Israil memiliki nabi lain selain Nabi Ibrahim as., Nabi Ismâ'il as., dan Nabi Mûsâ as. Ahmad Syalaby menyebutkan sembilan nabi Bani Israil dalam perspektif al-Qur’an, yaitu Ibrahim, Ismâ'il, Ishak, Ya'kub, Yûsuf, Mûsâ, Harûn, Dawûd, dan Sulaymân.13 Berdasarkan informasi al-Qur'an tadi, sementara ini ada dua kesimpulan penting yang bisa kita petik. Pertama, objek perintah zakat dalam syarî'ah Nabi Ibrahim as., Nabi Ismâ'il as., Nabi Mûsâ as sebagaimana terkandung dalam surat al-Anbiyâ' ayat 73 , surat Maryam ayat 55, dan surat al-Baqarah ayat 83 adalah mereka sendiri, umat mereka yang termasuk di dalamnya Bani Israil. Kedua, zakat adalah ritual turun-temurun agama samawi sejak Nabi Ibrahim as. hingga Nabi Muhammad saw.

12 Ali, Zakat sebagai Instrumen, hlm. 28.

${ }^{13}$ Ahmad Syalaby, Agama Yahudi (Jakarta: Bumi Aksara, 1991), hlm. 113. 
Tesis tadi seirama dengan pendapat Nuruddin Mhd. Ali. Menurutnya, "zakat merupakan ajaran yang universal karena diperintahkan kepada setiap umat pada setiap zaman dan merupakan salah satu risalah yang dibawa oleh para nabi dan rasul. Perbedaannya, mungkin hanya pada aspek teknis pelaksanaan perintah zakat, namun substansinya tetap sama, yaitu sebagai ibadah kepada Tuhan dan solidaritas sosial." 14 Demi membuktikan akurasi kebenaran tesis ini, maka enam ayat al-Qur'an tadi harus kita kaji lebih mendalam.

Jika menggunakan pendekatan historis, maka penelitian ini idealnya dirunut berdasarkan masa masing-masing nabi, yaitu dari Nabi Ibrahim as. hingga Nabi Isa as. Tetapi karena penelitian kali ini menggunakan pendekatan metodologi tafsir tematik yang menuntut adanya runtutan ayat yang merupakan objek penelitian berurutan berdasarkan sabab al-nuzĥl, maka urutan enam ayat di atas tetap pada urutan nomor yang sudah kita tetapkan sebelumnya, yaitu surat Maryam ayat 31 , ayat 55 , surat al-Anbiyâ' ayat 73 , surat al-Baqarah ayat 83 , surat al-Mâ'idah ayat 12 , dan surat al-Bayyinah 5 .

Berdasarkan pada penafsirannya atas surat Maryam ayat 31 yang dikutip oleh Ibn Katsîr, sarjana Muslim sekaliber Mâlik ibn Anas mengakui eksistensi zakat pada masa Nabi Isa as. Mâlik menyatakan Allah mengabari Nabi Muhammad saw. mengenai perkara yang ada pada saat Nabi Isa as. hidup hingga wafat. ${ }^{15}$ Meskipun dia tidak menyebutkan secara eksplisit jenis perkara itu, tetapi kuat dugaan salat dan zakat lah yang dia maksud. Dugaan ini bisa dibuktikan dengan tiadanya perkara lain dalam ayat ini selain salat dan zakat.

Guna mengetahui pengertian zakat dalam syarî'ah Nabi Isa as. dalam ayat tadi, maka kita harus mengetengahkan penafsiran alThabarî. Menurutnya, ada dua pengertian zakat. Pertama, zakat harta. Kedua, menyucikan badan dari dosa-dosa. Berdasarkan dua pengertian ini, dia menafsirkan potongan ayat " وأوصنى بالصلوة والزكوة" bahwa Allah memerintahkan Nabi Isa as. untuk meninggalkan dosa dan menjauhi maksiat. Selanjutnya dengan mengacu pada potongan ayat selanjutnya "ما دمت حيا", dia memperjelas pengertian zakat dalam ayat ini bahwa pengertian zakat dalam konteks ini adalah penyucian

${ }^{14} \mathrm{Ali}$, Zakat sebagai Instrumen, hlm. 28.

15Ibn Kathîr, Tafsîr al-Qur'ân al-'Aẓ̇̂m, juz 5, hlm. 229. 
badan dari dosa-dosa, karena Nabi Isa as. tidak menyimpan apa pun untuk keesokan harinya yang mewajibkan adanya zakat, kecuali sedekah dari sisa makanannya. ${ }^{16}$

Itu berarti pengertian zakat kedua itulah yang berlaku pada masa Nabi Isa as seperti halnya pengertian zakat pertama yang diajukan oleh Ibn Manzhûr pada uraian sebelumnya, yaitu al-zakâh juga bermakna al-shalâh (kesalehan). Pengertian semacam ini jelas berbeda dengan pengertian zakat pada syarî́ah Nabi Muhammad saw. yang lebih identik dengan pengertian pertama.

Surat Maryam ayat 31 di atas sedikit berbeda dari ayat 55 setelahnya. Bila ayat 31 Allah hanya memerintahkan Nabi Isa as. saja guna mendirikan salat dan menunaikan zakat, maka dalam ayat 55 Allah dengan lisan Nabi Ismâ'il as. memerintahkan sanak familinya mengerjakan dua hal tadi. Sayangnya, baik penafsiran al-Thabarî maupun penafsiran Ibn Katsîr atas ayat 55 ini tidak menyinggung persoalan zakat pada masa Nabi Ismâ'il as. secara detil. Al-Thabarî hanya menafsirkan bahwa dia memerintahkan keluarganya mendirikan salat dan menunaikan zakat serta kebaikan amal dan kepatuhan Nabi Ismâ'il as. di hadapan Allah. ${ }^{17}$ Dengan kata lain, objek perintah salat dan zakat meliputi Nabi Ismâ'il as. dan para kerabatnya. Tentu saja, berdasarkan penafsiran al-Thabarî, pengertian zakat dalam ayat 55 ini sama dengan pengertian zakat dalam ayat 31 sebelumnya.

Sayangnya, kita tidak menemukan informasi lebih detil dari Ibn Katsîr dan al-Thabarî dalam penafsirannya atas surat al-Anbiyâ' ayat 73, sehingga persoalan apakah pengertian zakat dalam syarî́ah Nabi Ibrahim as., Nabi Ishak as., dan Nabi Ya'kub as. sebagaimana terkandung dalam surat al-Anbiyâ' ayat 72 dan 73 sama dengan pengertian zakat dalam syarî'ah Nabi Muhammad saw. Dua penafsir terhormat tersebut tidak merincinya dalam karya tafsirnya. Keterangan tambahan dari sawâbiq dan lawâhiq ayat 73 juga tidak mengarah pada persoalan zakat, tetapi hanya secuil cerita seputar Nabi Ibrahim as. ketika dibakar, penganugerahan hikmah dan ilmu pada Nabi Lut as., dan Nabi Nuh as.

16Al-Thabarî, Jâmi' al-Bayân, juz 15, hlm. 531.

17Ibid., hlm. 562. Lihat juga Ibn Katsîr, Tafsîr al-Qur'ân al-'Azîm, juz 5, hlm. 240. 
Meskipun demikian, persoalan eksisensi zakat serta perbedaan pengertiannya antara syari' $a h$ Nabi Muhammad saw. dan syarî'ah para nabi sebelumnya semakin dikukuhkan oleh penafsiran Ibn 'Abbâs, penafsir terkemuka dari generasi sahabat, atas surat al-Baqarah ayat 83. Menurutnya, sebagaimana dinukil oleh Al-Thabarî, maksud ayat " لوأتوا الزكوة" dalam ayat ini adalah mengeluarkan zakat dari harta Bani Isra'il sebagaimana Allah telah mewajibkan kepada mereka. Ini merupakan sunnah mereka, bukan sunnah Muhammad saw. ${ }^{18}$

Ketiadaan informasi pendukung mengenai detil persoalan zakat dalam syarî'ah terdahulu terdapat dalam penafsiran al-Thabarî dan Ibn Katsîr atas ayat objek penelitian selanjutnya, yaitu surat alMâ'idah ayat 12. Oleh karena itu, kita tidak bisa mengandalkan penafsiran mereka berdua guna menyingkap detil persoalan zakat dalam surat al-Mâ'idah ayat 12, kecuali hanya pengakuan tersirat tentang eksistensi perintah zakat pada Bani Israil sebagaimana makna lahir ayat ini. Begitu juga sawâbiq dan lawâhiq ayat ini tidak membantu menemukan detil persoalan zakat.

Begitu juga terjadi pada ayat objek penelitian yang terakhir, surat al-Bayyinah ayat 5 . Kita tidak menemukan informasi detil kecuali dari makna lahir ayat tentang eksistensi. Perbedaannya hanya pada objek perintah zakat. Jika objek surat al-Mâ'idah ayat 12 adalah Bani Israil, maka objek surat al-Bayyinah ayat 5 adalah Ahli Kitab yang kafir dan kaum musyrik yang, sebagaimana kandungan surat alBayyinah ayat 1, 2, dan 3, menuntut bukti nyata berupa seorang utusan dari Allah yang membacakan lembaran-lembaran suci yang berisi kandungan kitab-kitab yang diturunkan pada para nabi sebelumnya, yaitu Taurat, Zabur, dan Injil yang masih murni. Kuat dugaan bahwa sebagian isi kitab-kitab itu mencakup perintah mengesakan Allah, memurnikan ketaatan pada-Nya dalam menjalankan agama yang lurus, mendirikan salat, dan menunaikan zakat sebagai syarat, sebagaimana kandungan surat al-Bayyinah ayat 5 , agama yang lurus.

Dari data di atas, setidaknya kita bisa menyimpulkan dua hal. Pertama, meskipun kita tidak bisa memastikan awal mula penerapan kewajiban zakat karena keterbatasan data, tetapi kita dengan yakin bisa memastikan sangat pentingnya kedudukan zakat dalam agama

18Al-Thabarî, Jâmi' al-Bayân, juz 2, hlm. 198. 
samawi, karena ia merupakan syarat mutlak kelurusan agama seseorang sejak Nabi Ibrahim as. hingga Nabi Muhammad as. Kedua, menurut Abdurrahman Qadir, sebagaimana dikutip Nuruddin Mhd. Ali, penerapan zakat pada umat-umat sebelum Islam belum merupakan suatu perintah yang mutlak dan ilzâmî, tetapi bersifat solidaritas dan rasa belas kasihan (karitatif) dalam rangka menyantuni orang-orang miskin. Barulah dalam syarî'ah Islam zakat ditetapkan menjadi suatu kewajiban yang bersifat mutlak dan menjadi salah satu rukun Islam. ${ }^{19}$

Kita bisa menjelaskan pendapat Abdurrahman Qadir tersebut dengan pernyataan Ahmad Syalabi bahwa agama Islam menitikberatkan pada hukum-hukum syarî'ah (undang-undang), sedangkan agama Masehi tidak mementingkan masalah ini. ${ }^{20}$ Dengan kata lain, Islam lebih menitikberatkan pada aspek perundangan atau syarî'ah, sementara agama Masehi menitiberatkan pada aspek kasih sayang atau rahmat.

Salah satu bukti Islam lebih menitikberatkan syarî'ah adalah: selain sekitar 20 ayat al-Qur`an, Hadits juga banyak mengandung doktrin-doktrin termasuk di dalamnya persoalan zakat. Menurut Abû Yahyâ al-Nawâwî, sebagaimana dikutip oleh Nuruddin Mhd. Ali, alBukhârî (194-256 H) dan Muslim (206-261 H) telah menghimpun sekitar 800 Hadits yang berkaitan dengan zakat, termasuk beberapa atsâr. ${ }^{21}$ Sayangnya, tidak ada satu pun koleksi Hadits zakat al-Bukhârî dan Muslim yang secara detil menyinggung persoalan zakat dalam syarî'ah terdahulu. Tidak ada satu pun Hadits koleksi shahîh Muslim yang menyinggung persoalan zakat dalam syarîah terdahulu, sedangkan dalam shahîh al-Bukhârî hanya Hadits nomer 1498 dalam kitab zakat yang merupakan satu-satunya Hadits 'zakat [?]' Bani Israil. Itu pun sebenarnya tidak ada sangkut-pautnya dengan persoalan zakat. Teks Hadits tersebut sebagai berikut:

وقال الليث: حدثنى جعفر بن ربيعة عن عبد الرحمن بن هرمز عن أبى هريرة رضي الله عنه عن النبى

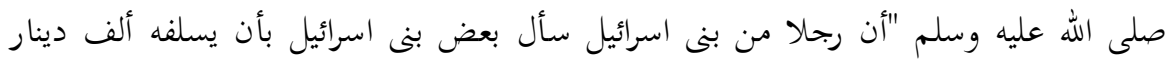

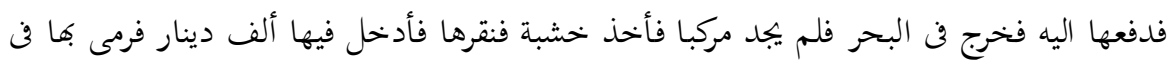

${ }^{19}$ Ali, Zakat sebagai Instrumen, hlm. 28.

20 Syalaby, Agama Yahudi, hlm. xiv.

${ }^{21}$ Ali, Zakat sebagai Instrumen, hlm. 26-27. 


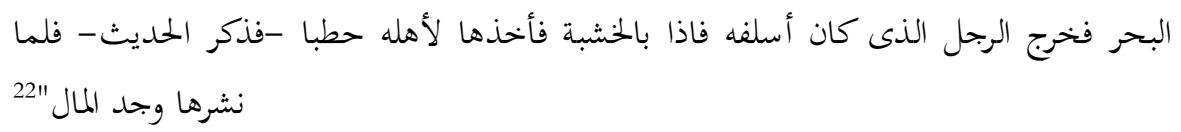

Al-Layts berkata, "Ja'far ibn Rubay'ah mengabarkan pada kami dari 'Abd al-Rahmân ibn Hurmaz dari Abû Hurayrah ra. dari Nabi Saw., "Sesungguhnya ada seorang laki-laki Bani Israil meminta pada sebagian Bani Israil untuk meminjaminya 1000 dinar. Mereka pun memberinya. Lalu dia keluar ke laut, tetapi tidak menemukan perahu. Dia pun mengambil sepotong kayu dan melubanginya lantas memasukkan 1000 dinar ke dalamnya. Lalu dia melemparkannya ke laut. Kemudian lakilaki yang memberinya pinjaman itu keluar dan menemukan kayu tadi lantas mengambilnya untuk keluarganya untuk dijadikan kayu bakar lalu dia menyebutkan Hadits- kemudian ketika dia menggergaji kayu itu, dia menemukan uang tersebut."

\section{Penutup}

Meskipun tidak ada satu pun koleksi Hadits shahîh $\underline{h}$ al-Bukhârî dan shahîh Muslim tentang zakat dalam syarî'ah terdahulu, tetapi alQur`an memberikan sedikit informasi tentang eksistensi zakat dalam syarî'ah sebagian nabi pra Nabi Muhammad Saw., yaitu Nabi Ibrahim as., Nabi Ismâ'il as., Nabi Mûsâ as., dan Nabi Isa as. Sebagaimana lazim diketahui, setiap umat memiliki syir'ah dan minhâj yang berbeda satu sama lain. Begitu pula persoalan teknis perintah penerapan zakat. Dalam hal ini, pengertian zakat mengalami evolusi signifikan dari masa ke masa. Evolusi ini mengingatkan kita pada konsep gradualisasi doktrin Islam. Bisa jadi evolusi pengertian zakat itu merupakan dari gradualisasi doktrin agama samawi. Dengan kata lain, gradualisasi doktrin tidak hanya berlaku pada syarî'ah nabi tertentu, tetapi juga berlaku pada syarî'ah lintas generasi para nabi. Evolusi pengertian zakat termasuk gradualisasi doktrin agama samawi lintas generasi para nabi ini. Sedikit ulasan tentang zakat dari Ibn 'Abbâs, 'Abd al-Rahnman ibn al-Qâsim, al-Thabarî, Ibn Katsîr, dan

${ }^{22} \mathrm{Abū} \mathrm{'Abd} \mathrm{Allâh} \mathrm{Muhammad} \mathrm{ibn} \mathrm{Ismâ'îl} \mathrm{al-Bukhârî,} \mathrm{Al-Jâmi'} \mathrm{al-shahîh} \underline{h}$ al-Musnad min hadîth Rasūl Allâh shallâ Allâh 'alayhi wa Sallama wa Sunanihi wa Ayyâmihi, juz 1 (Kairo: al-Salafiyah, $1400 \mathrm{H}$ ), hlm. 464. Penulis memberi tanda petik dan tanda tanya pada kata zakat di atas karena al-Bukhârî mencantumkan Hadits ini dalam kitab zakat bab mâ yustakhraj min al-bahr. Padahal sependek pengetahuan penulis, Hadits ini tidak ada sangkut-pautnya dengan persoalan zakat, tetapi lebih pada persoalan pinjaman. 
Ibn Manzhûr di atas adalah bukti evolusi itu. Selain itu, ada kesimpulan lain yang kita dapat, yaitu keserasian antara definisi zakat dengan realitas penerapannya. Itu terbukti dengan dua definisi zakat yang dikemukakan oleh Ibn Manzhûr dan al-Thabarî. Definisi zakat pertama Ibn Manzhûr berlaku pada syarî'ah terdahulu, sedangkan definisi keduanya berlaku pada syarî́ah Nabi Muhammad saw. Definisi zakat al-Thabarî sebaliknya. Meskipun syir'ah dan minhâj setiap umat berbeda, termasuk zakat, tetapi tugas mereka semua adalah berlomba-lomba dalam kebajikan.

\section{Daftar Pustaka:}

Ali, Nuruddin Mhd. Zakat sebagai Instrumen dalam Kebijakan Fiskal. Jakarta: RajaGrafindo Persada, 2006.

Audah, Ali. Konkordansi Qur'an: Panduan Kata dalam Mencari ayat Qur'an. Bogor: Pustaka Litera AntarNusa, 1997.

Bâqî, Muhammad Fu'âd 'Abd al-. al-Mu'jam al-Mufahras li Alfâzh alQur'ân al-Karîm. (Kairo: Dâr al-Hadîts, 1939.

Bukhârî, Abū 'Abd Allâh Muhammad ibn Ismâ'îl al-. Al-Jâmi' al-shahîh al-Musnad min hadîth Rasūl Allâh shallâ Allâh 'alayhi wa Sallama wa Sunanihi wa Ayyâmihi. Kairo: al-Salafiyah, 1400 H.

ibn Katsîr, Abū al-Fidâ' Ismâ'îl ibn 'Umar al-Qurasyî al-Dimasyqî. Tafsîr al-Qur'ân al-'Azhîm. (Riyad: Dâr al-Thaybah, 1999.

Ibn Manzhûr, Lisân al-'Arab (Kairo: Dâr al-Ma'ârif, t.t.

Thabarî, Abû Ja'far Muhammad ibn Jarîr al-. Jâmi' al-Bayân 'an Ta'wîl Âyi al-Qur'ân. Kairo: Dâr Hijr, 2001. 